\title{
INDUCIBLE PROTEINASE OF CANDIDA ALBICANS IN DIAGNOSTIC SEROLOGY AND IN THE PATHOGENESIS OF SYSTEMIC CANDIDOSIS
}

\author{
Fiona Macdonald and F. C. Odds \\ Department of Microbiology, University of Leicester, Leicester LEI 7RH
}

\section{Plate XVII}

THERE are difficulties in the diagnosis of deep-seated candidosis; the clinical features are non-specific and similar to bacterial infections, and blood cultures may be negative even when there is an active invasion of the deep tissues.

Serology, especially precipitin tests, are considered a useful diagnostic adjunct (Taschdjian, Seelig and Kozinn, 1973; Odds, 1979) but precipitins to extracts of Candida albicans have been detected in sera from apparently normal subjects (Douchet and Müller, 1972; Everall, Morris and Morris, 1974), pregnant women (Stanley, Hurley and Carroll, 1972), burned patients (Oblack, Schwartz and Holder, 1976), patients given intravenous hyperalimentation (Glew et al., 1975) and in patients after open heart surgery (Murray, Buckley and Turner, 1969; Parsons and Nassau, 1974; Evans and Forster, 1976). These 'false positive' antibodies may often be directed to the cell-wall mannans of C. albicans (Pepys et al., 1968).

Although attempts have been made to introduce new tests for candida antibodies (Stickle et al., 1972; Müller, 1974) it is unlikely that any serological test can be more specific than the antigenic reagents on which it is based. Most efforts to overcome the problem of poor specificity have involved either the modification of candida extracts by removal of the mannan antigens (Longbottom et al., 1976; Syverson and Buckley, 1977; Syverson, Buckley and Gibian, 1978) or a search for novel antigenic components unique to the hyphal form of the fungus (Evans et al., 1973; Syverson, Buckley and Campbell, 1975). Staib and his co-workers (1977a and $b$ ) have suggested that an inducible acid proteinase secreted by $C$. albicans may be a useful diagnostic antigen; but they appear to have tested only unrefined culture filtrates containing the enzyme, with equivocal results.

This paper describes a simple method for the rapid purification of $C$. albicans proteinase which is a development of the procedure of Remold, Fasold and Staib (1968). The value of the purified enzyme as an antigen for use in the diagnosis of systemic candidosis is assessed in tests with sera from experimental animals and humans. 


\section{MATERIALS AND METHODS}

Cultures. C. albicans strain ATCC28366 alone was used and maintained on SabouraudDextrose Agar (SDA) (Difco). Inocula were prepared from cultures grown on SDA for $18 \mathrm{~h}$ at $37^{\circ} \mathrm{C}$. Yeasts were washed from the slope with phosphate-buffered saline (PBS), centrifuged for $10 \mathrm{~min}$. at $2500 \mathrm{~g}$ and resuspended in distilled water; cell densities were determined with a haemocytometer. C. albicans was routinely added to growth media to give an initial yeast concentration of $10^{6} / \mathrm{ml}$.

The culture medium used for large-scale induction of proteinase by C. albicans was modified from that of Remold et al. (1968), by the use of a synthetic vitamin solution. The composition per $1000 \mathrm{ml}$ of water was: glucose, $20 \mathrm{~g}$; bovine serum albumin (Fraction V, Sigma, from London Chemical Co., Fancy Rd, Poole, Dorset), $2 \mathrm{~g} ; \mathrm{KH}_{2} \mathrm{PO}_{4}, 1 \mathrm{~g} ; \mathrm{MgSO}_{4} .7 \mathrm{H}_{2} \mathrm{O}, 0.5 \mathrm{~g}$; biotin, $20 \mu \mathrm{g}$; nicotinic acid, $400 \mu \mathrm{g}$; pyridoxal hydrochloride, $400 \mu \mathrm{g}$; riboflavin, $200 \mu \mathrm{g}$; thiamine hydrochloride, $400 \mu \mathrm{g}$. Six flasks, each containing 1.5 litres of culture, were incubated at $26^{\circ} \mathrm{C}$ and shaken at 160 r.p.m.

Purification of proteinase. After 7 days' growth, enzyme activity in the culture filtrate was maximal and the $p \mathrm{H}$ had fallen to $2 \cdot 9$. At this stage $C$. albicans cells were removed by centrifugation at $5000 \mathrm{~g}$ for $30 \mathrm{~min}$. The culture filtrate was passed through $0.8-\mu \mathrm{m}$ membrane filters to ensure the removal of any remaining yeast cells and the $p \mathrm{H}$ was adjusted to 6.5 with $3 \mathrm{M}$ $\mathrm{NaOH}$.

Dry DEAE-Sephadex A-25-120 (Pharmacia) was added to the filtrate at a concentration of $20 \mathrm{~g} /$ litre. The mixture was shaken and left overnight at $4^{\circ} \mathrm{C}$ to ensure complete adsorption of the enzyme and swelling of the ion exchanger. The DEAE-Sephadex was removed by filtration on a Buchner funnel and transferred to a glass column to give a final bed size of $30 \mathrm{~cm} \times 5.5 \mathrm{~cm}$. No detectable enzyme activity remained in the supernatant fluid.

Proteins were eluted from the column with batches of sodium citrate buffer, $p \mathrm{H} \mathrm{6.5}$, of increasing ionic strength; $50-\mathrm{ml}$ fractions were collected at a flow rate of $25 \mathrm{ml} / \mathrm{min}$. The absorbance of each fraction at $280 \mathrm{~nm}$ was determined against a citrate-buffer blank and representative fractions containing ultraviolet-absorbing material were assayed for proteinase activity. The enzyme-rich fractions were pooled and concentrated approximately sevenfold by ultrafiltration with DM5 Diaflo Membranes (Amicon Corp., Amicon House, Kingsway, Woking, Surrey). Brij 35 (Sigma) solution (100 g/litre) was added to the enzyme solution at a concentration of $2 \%(\mathrm{v} / \mathrm{v})$ to stabilise the enzyme, which was then sterilised by membrane filtration and stored in 5-ml lots at $4^{\circ} \mathrm{C}$. The purified proteinase (PP) was very stable and showed little loss of activity after 3 months.

Assay of proteinase. Of the solution containing the enzyme, $0.5 \mathrm{ml}$ was incubated with $2 \mathrm{ml}$ of bovine serum albumin solution $(10 \mathrm{~g} /$ litre) in $0.05 \mathrm{M}$ sodium citrate buffer, $p \mathrm{H} 3 \cdot 2$, for $30 \mathrm{~min}$. The reaction was stopped by addition of $5 \mathrm{ml}$ of trichloroacetic acid solution (TCA) ( $50 \mathrm{~g} /$ litre). Albumin was removed by filtration through a $0 \cdot 8-\mu \mathrm{m}$ membrane Type AA (Millipore, Corp., Bedford, Mass., USA). The amount of proteolysis was determined by measuring the absorbance of the filtrate at $280 \mathrm{~nm}$ against a citrate-buffer blank. Control samples containing only substrate had $0.5 \mathrm{ml}$ of enzyme added after TCA precipitation of the albumin at $30 \mathrm{~min}$.

Assay of protein was by the method of Lowry et al. (1951). Spectrophotometric readings were made at $500 \mathrm{~nm}$ and converted to $\mu \mathrm{g}$ of protein per $\mathrm{ml}$ from a bovine serum-albumin standard curve.

Analysis of carbohydrates. Samples of $\mathrm{PP}$ were hydrolysed for $3 \mathrm{~h}$ with $5 \mathrm{~N} \mathrm{HCl}$ at $100^{\circ} \mathrm{C}$ and then dried in vacuo over phosphorus pentoxide and sodium hydroxide. Detectable sugars were not released by shorter periods of hydrolysis. Sugars in the hydrolysed sample were identified by two-dimensional thin-layer chromatography (TLC) (Hotta and Kurokawa, 1968). Total hexose concentration was determined spectrophotometrically with anthrone reagent (Spiro, 1966) by reference to a mannose standard.

Cytoplasmic antigen (CE) was prepared as described by Odds, Evans and Holland (1975) and stored at $-70^{\circ} \mathrm{C}$ without lyophilisation.

Polyacrylamide-gel electrophoresis (PAGE). Samples of proteinase were examined for 
purity by polyacrylamide gel electrophoresis (Davis, 1964). Samples containing $1.15 \mathrm{mg}$ of Lowry protein were prepared in sucrose solution $(400 \mathrm{~g} /$ litre), with bromophenol blue as a marker, and applied to $10 \%$ gels in tubes. Gels were electrophoresed at a constant current of $5 \mathrm{~mA}$ per gel for $3 \mathrm{~h}$. They were stained overnight for protein with Page Blue 83 (BDH Chemicals Ltd, Poole, Dorset) $2.5 \mathrm{~g} /$ litre in a solution of trichloroacetic acid $(50 \mathrm{~g} /$ litre in methanol:water, 1:1) and destained with the dye-free solvent.

Samples of PP and CE, containing $0.23 \mathrm{mg}$ of Lowry protein, were compared by horizontalslab gel electrophoresis in a $10 \%$ gel. These gels were run at a constant current of $40 \mathrm{~mA}$ for $5 \mathrm{~h}$, then stained and destained as above.

Inhibition of enzyme. The effect of various inhibitors on proteinase activity was investigated. The inhibitors, all obtained from Sigma Ltd, London, were added to $0.5 \mathrm{ml}$ of enzyme solution from tenfold concentrated stock solutions to give the following final concentrations: dithiothreitol + EDTA (each $2 \mathrm{mM})$, pepstatin $(10 \mu \mathrm{g} / \mathrm{ml})$, phenanthroline (1mM), phenyl methyl sulphonyl fluoride $(1 \mathrm{~mm})$ and soybean trypsin inhibitor $(100 \mu \mathrm{g} / \mathrm{ml})$. The mixtures were incubated for 30 min. at $37^{\circ} \mathrm{C}$ then activity was assayed as before.

Serological tests. Immunoelectrophoresis was performed according to Grabar and Williams, (1953), and crossed immunoelectrophoresis by the microplate method of Axelsen, Krøll and Weeke (1973). Tandem crossed immunoelectrophoresis of PP and CE was performed as described by Axelsen et al. (1973), except that the antigens were electrophoresed for $90 \mathrm{~min}$ in the first dimension at $10 \mathrm{~V} / \mathrm{cm}$ and for $30 \mathrm{~h}$ in the second dimension at $3 \mathrm{~V} / \mathrm{cm}$. In all immunoelectrophoresis experiments, antigens were used at $23 \mathrm{mg}$ of Lowry protein $/ \mathrm{ml}$.

Antisera raised against the two antigens were compared by crossed immunoelectrophoresis with intermediate gel under the same conditions as above.

Precipitating antibodies to CE and PP antigens at $2.3 \mathrm{mg} / \mathrm{ml}$ were detected by counterimmunoelectrophoresis (CIE) (Odds, et al., 1975). Sera were serially diluted and the precipitin titre of the serum was recorded.

Antisera. Antiserum to PP was raised in New Zealand white rabbits by a schedule that involved cutaneous and intravenous inoculations. For subcutaneous injection, equal volumes of PP solution containing $23 \mathrm{mg}$ of Lowry protein $/ \mathrm{ml}$ and Freund's incomplete adjuvant were emulsified by ultrasonication; $0 \cdot 5-\mathrm{ml}$ lots were administered twice weekly for 3 weeks. For intravenous inoculations equal volumes of proteinase and a latex-particle suspension (Difco) diluted 1 in 20 were mixed and $0.5 \mathrm{ml}$ of the mixture was injected weekly for 3 weeks. The animals were bled from the marginal ear vein 7 days after the last inoculation. The serum was stored at $-20^{\circ} \mathrm{C}$ before use.

Antiserum to $\mathrm{CE}$ antigen was raised by a schedule of subcutaneous inoculation only. Equal volumes of CE $(20 \mathrm{mg}$ protein $/ \mathrm{ml})$ and Freund's incomplete adjuvant were emulsified by ultrasonication; $0.5-\mathrm{ml}$ lots of the emulsion were then given subcutaneously to rabbits, twice weekly for five injections. Animals were bled 7 days after the final inoculation.

Serum samples from rabbits experimentally infected with $C$. albicans and from hospital patients were tested retrospectively for precipitins to CE and PP.

Three rabbits had been given an intravenous injection of C. albicans $4 \times 10^{5}$ cells $/ \mathrm{kg}$. This dose led to a chronic systemic infection; the animals were bled 10, 14 and 42 days after inoculation. Six rabbits were given an intravenous injection of C. albicans $5 \times 10^{6} / \mathrm{kg}$, a dose known to produce a rapidly fatal disseminated candidosis; three of these rabbits, which were treated orally with ketoconazole (Janssen Pharmaceuticals, Ltd, Marlow, Bucks) from 1 to 7 days after injection, survived for 30 days (Odds $e t$ al., 1980) and blood was obtained from them at 10,14, 22 and 30 days after inoculation. The three untreated animals died 6 days after injection and from these untreated rabbits the only serum samples used were taken before injection.

Human serum was from patients or healthy volunteers in one of four groups. Many were obtained through the co-operation of the Mycological Reference Laboratory, London School of Hygiene and Tropical Medicine, the Mycology Unit, Leeds General Infirmary, and the Public Health Laboratory, Leicester. The 57 normal individuals in group 1 were healthy staff and students at Leicester University. The 38 subjects in group 2 were hospital patients with no known microbiological, histological or serological evidence of deep-seated candidosis. Group 3 
comprised 26 patients, of whom 17 had undergone cardiac surgery 1-3 weeks before serum was obtained, and another 9 in whom the clinical history was uncertain. All the serum samples from the patients in group 3 contained precipitating antibodies to $C$. albicans $C E$ but other evidence of systemic candidosis was not available. These sera were termed 'false positive' although it was recognised that some of the group-3 patients may have suffered from a systemic candidal infection. Group 4 contained 18 patients all diagnosed as cases of systemic candidosis on microbiological or pathological criteria or both. They included eight cases of disseminated candidosis, four of $C$. albicans endocarditis, one of $C$. glabrata endocarditis, two of renal candidosis, and one each of secondary pulmonary candidosis, oesophageal candidosis and chronic mucocutaneous candidosis. Serial serum specimens were obtained from some of the patients in group 4.

Immunofluorescence. Mice were given an intravenous injection of C. albicans $10^{6}$ cells and were killed after 3 days. The kidneys were removed, embedded in Tissue Tek Fluid (Raymond Lamb, Sunbeam Rd, North Acton, London) and frozen in liquid nitrogen. Tissue sections, 6 $\mu \mathrm{m}$ thick, were cut on a cryostat, fixed in a stream of hot air and stained for proteinase by an indirect immunofluorescent method. Three drops of a 1 in 10 dilution of anti-PP serum were added to each section on a slide and the slides were incubated at room temperature in a humid box for $30 \mathrm{~min}$. The slides were washed for $30 \mathrm{~min}$, with PBS then stained for $30 \mathrm{~min}$. with a 1 in 80 dilution of swine fluorescein-conjugated anti-rabbit immunoglobulins (DAKO, Mercia Brocades Ltd, West Byfleet, Surrey). After a final washing as before, the slides were mounted in glycerol and examined for fluorescence with a Leitz ultraviolet microscope. Photographs were taken with an Ilford HP5 film (ASA 400) and developed with Microphen (Ilford) to give the film a final rating of 1600 ASA.

\section{RESULTS}

\section{Purification of C. albicans proteinase}

The stages of purification of C. albicans proteinase are summarised in table I; details of the elution of proteinase from DEAE-Sephadex are shown in fig. 1 . A peak of ultraviolet-absorbing material, probably containing albumin, was eluted by $0.03 \mathrm{M}$ citrate buffer. In $0.05 \mathrm{M}$ buffer a peak with proteinase activity was eluted from the column. Higher strengths of buffer did not elute any more ultraviolet-absorbing material. The purification was repeated four times, each with similar elution profiles. The apparently small increase of specific activity of the purified enzyme compared with the unrefined culture filtrate was attributed to the presence of substances of low molecular weight that gave positive reactions in the assay of Lowry protein. The true protein content of

TABLE I

Summary of purification of C. albicans proteinase

\begin{tabular}{|c|c|c|c|c|c|}
\hline Sample & $\underset{(\mathrm{ml})}{\text { Volume }}$ & $\begin{array}{l}\text { Concentration } \\
\text { of Lowry } \\
\text { protein } \\
(\mathrm{mg} / \mathrm{ml})\end{array}$ & $\begin{array}{c}\text { Specific } \\
\text { activity } \\
\left(\mathrm{OD}_{280} / \mathrm{min}\right. \\
\text { per } \mathrm{mg} \text { of protein })\end{array}$ & $\begin{array}{c}\text { Total } \\
\text { activity } \\
\left(10^{3} \mathrm{OD}_{280} / \mathrm{min}\right)\end{array}$ & $\underset{\text { (percent) }}{\text { Yield }}$ \\
\hline $\begin{array}{l}\text { Culture filtrate } \\
\text { Pooled fractions }\end{array}$ & 9000 & 1.6 & $3 \cdot 3$ & 47.5 & $100 \cdot 0$ \\
\hline $\begin{array}{l}\text { from DEAE-Sephadex } \\
\text { Concentrated enzyme }\end{array}$ & $\begin{array}{r}400 \\
20\end{array}$ & $\begin{array}{r}2 \cdot 0 \\
23 \cdot 0\end{array}$ & $\begin{array}{l}6 \cdot 3 \\
4 \cdot 8\end{array}$ & $\begin{array}{l}5 \cdot 1 \\
2 \cdot 2\end{array}$ & $\begin{array}{r}10 \cdot 6 \\
4 \cdot 7\end{array}$ \\
\hline
\end{tabular}




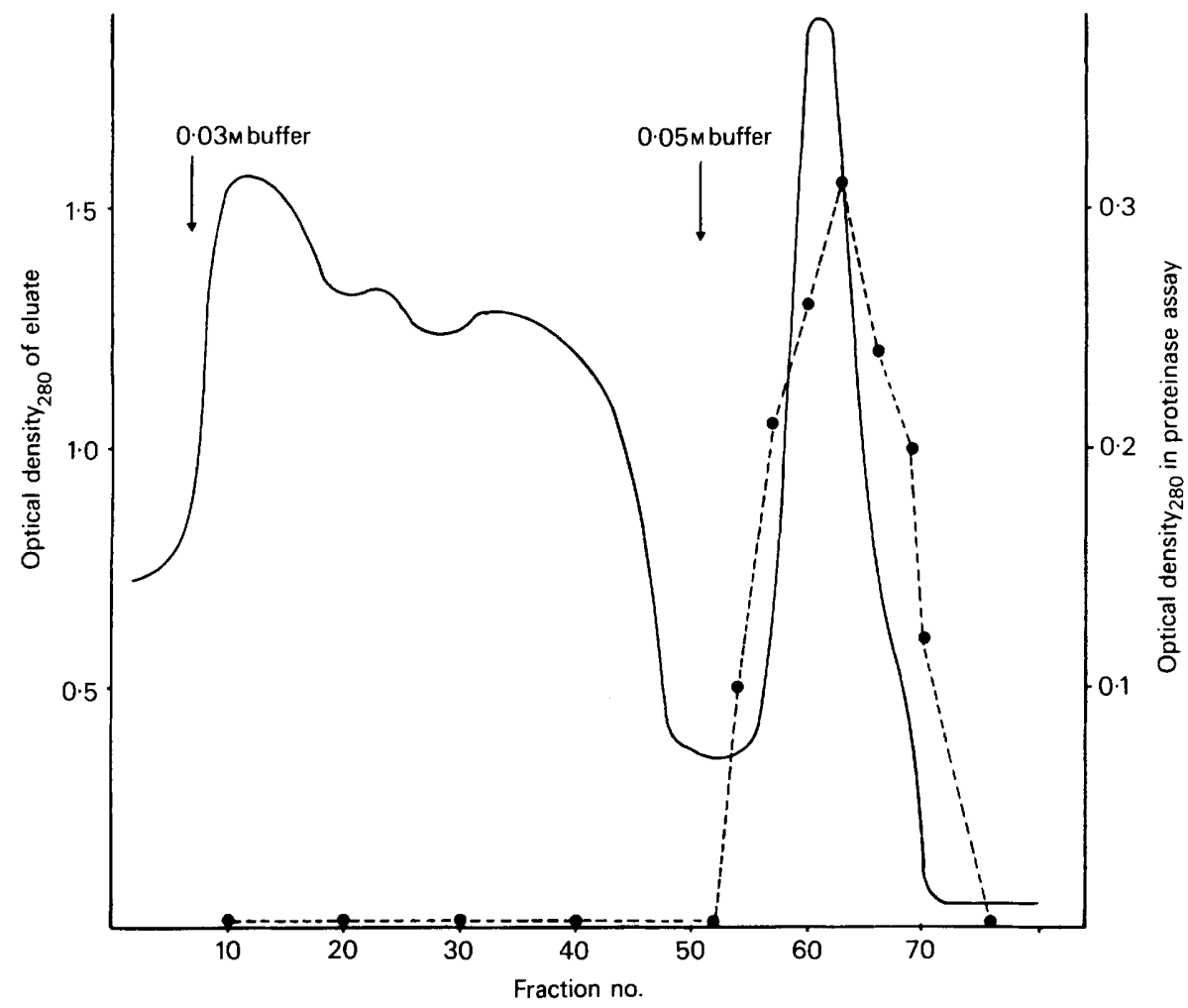

Fig. 1.-Elution of $C$. albicans proteinase from DEAE-Sephadex. Molarities arrowed refer to changes of citrate-buffer eluant. $\longrightarrow=\mathrm{OD}_{280 \mathrm{~nm}}$ of eluate; $\bullet--\bullet=\mathrm{OD}_{280 \mathrm{~nm}}$ in proteinase assay.

PP preparations was therefore smaller than indicated in table 1. The contaminants could be removed from PP by chromatography on Sephadex G25 (unpublished data); however, this procedure was not performed routinely because the contaminants of low molecular weight appeared to have no effect on the biochemical or serological behaviour of PP preparations.

The macromolecular purity of the proteinase preparation was demonstrated by PAGE and by serological tests. The enzyme migrated as a single protein band in polyacrylamide gels (fig. 2). In gels run with reverse polarity no protein bands at all were observed. In conventional immunoelectrophoresis tests with purified proteinase and homologous rabbit antisera, only one precipitin arc was seen (fig. 3) and the purified enzyme gave only one peak in two-dimensional crossed-immunoelectrophoresis tests (fig. 4). The enzyme bands on PAGE gels and the precipitin arcs in the serological tests were somewhat diffuse in nature, a characteristic of $C$. albicans glycoproteins noted by Odds and Hierholzer (1973).

\section{Biochemical tests}

The presence of carbohydrate in the molecule was confirmed by tests with 

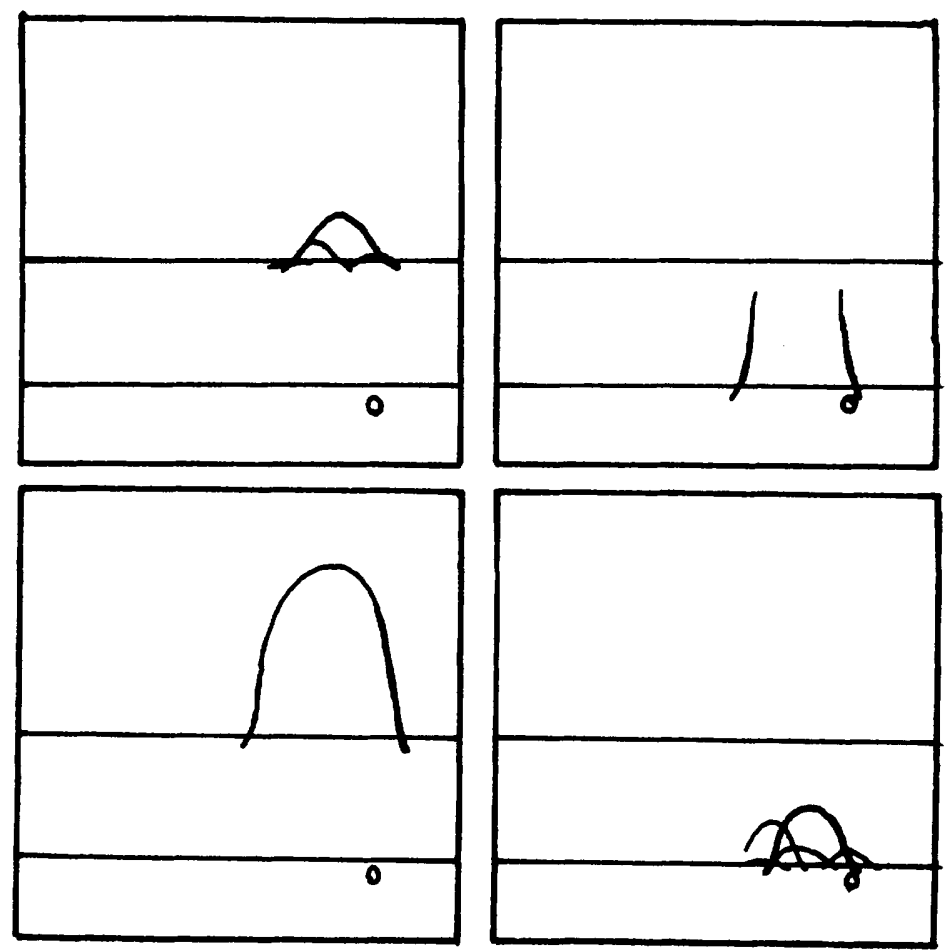

FIG. 4.-Two-dimensional crossed immunoelectrophoresis of $C$. albicans CE and PP antigens with intermediate gel. Top left; $\mathrm{CE}$ antigen ( $46 \mathrm{ng}$ ) with anti-PP in intermediate gel, anti-CE in reference gel (both at $50 \mu \mathrm{l} / \mathrm{ml}$ of agarose). Top right, PP antigen (46 $\mathrm{ng}$ ), antisera as in plate top left. Bottom left, PP antigen, anti-CE in intermediate gel $(70 \mu \mathrm{l} / \mathrm{ml}$ of agarose). Bottom right, $\mathrm{CE}$ antigen, antisera as in plate bottom left.

anthrone reagent. The sugar in the proteinase hydrolysates was identified by TLC as mannose ( $\mathrm{Rf}$ values were 0.31 in the first dimension and 0.13 in the second dimension, compared with 0.32 and 0.13 respectively for a reference sample of pure mannose).

The proteinase activity of the purified enzyme was inhibited by pepstatin, over a wide range of concentrations. No other enzyme inhibitor among those tried had any effect, including diazo nor-leucine methyl ester, which is normally an inhibitor of the same group of proteinases as pepstatin, but the methyl ester is known to react slowly with some enzymes.

\section{Immunological properties}

PP and CE antigens were compared to determine whether any of the components of the cytoplasmic extract had enzyme activity and to establish whether purified proteinase was antigenically distinct from the components of CE.

On slab PAGE gels one band of the cytoplasmic antigen ran in the same position as the proteinase antigen, with $\mathrm{Rf} 0.45$; however, when the cytoplasmic extract was assayed for proteinase at $p \mathrm{H} 3 \cdot 2$, activity was not detected. 


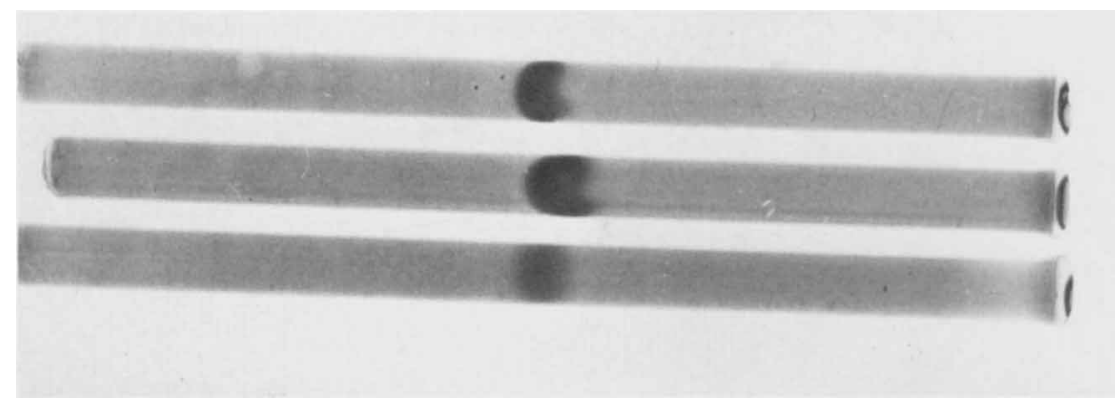

FIG. 2.-Purity of $C$. albicans proteinase demonstrated by polyacrylamide-gel electrophoresis. Top, proteinase batch $1,1150 \mu \mathrm{g}$ protein applied to gel; centre and bottom, proteinase batch 2, 1150 and $460 \mu \mathrm{g}$ protein respectively applied to gel.

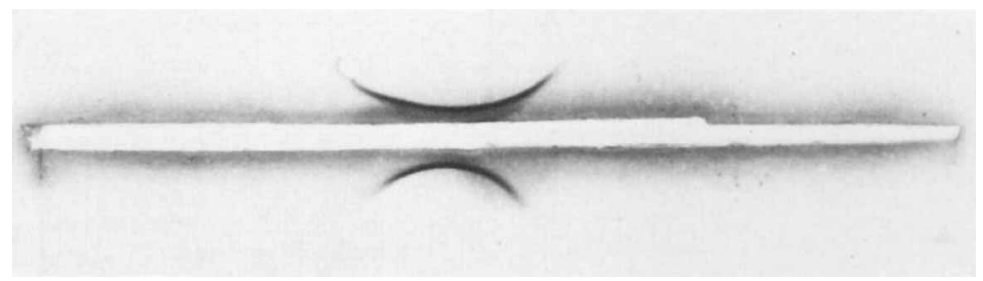

FIG. 3.-Precipitin arc with purified C. albicans proteinase and homologous antiserum. Top well, proteinase batch 1, $230 \mu \mathrm{g}$ protein; bottom well, proteinase batch 2, $160 \mu \mathrm{g}$ protein. Antiserum in trough, anode to left.

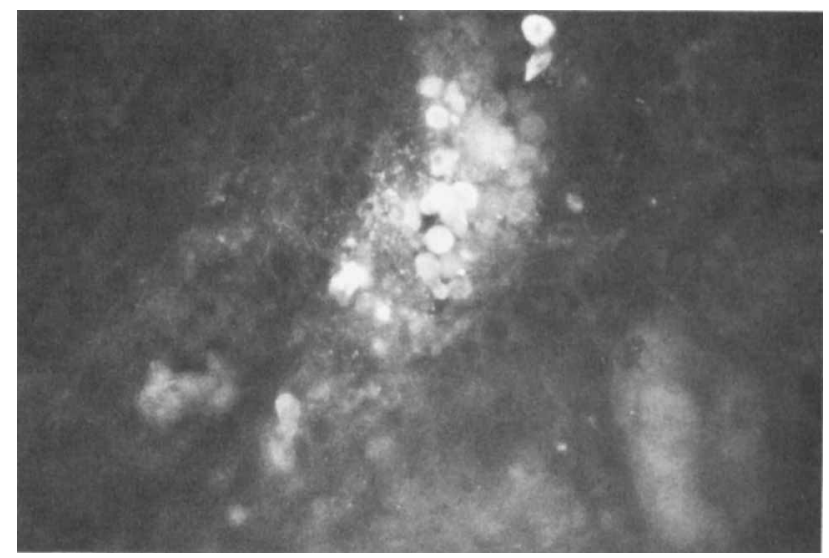

FIG. 5.-Indirect fluorescent antibody test for C. albicans proteinase in experimental murine kidney lesion. Note fluorescent yeasts and halo of fluorescence in immediate vicinity of yeasts indicative of proteinase secretion in vivo. $\times 1000$. 
The antigens were further compared by tandem crossed immunoelectrophoresis and by two-dimensional crossed immunoelectrophoresis with intermediate gel (fig. 4) and anti-PP and anti-CE rabbit sera. In neither test was there any visible cross reaction between $\mathrm{PP}$ or $\mathrm{CE}$ and heterologous antiserum. The low number of precipitin peaks seen with anti-CE sera may have been due to a weak antibody response in the animal inoculated.

\section{Immunofluorescence}

Fig. 5 shows the results obtained when infected mouse kidney tissue was stained for proteinase by the indirect immunofluorescent technique. Weakly fluorescent yeast cells of $C$. albicans could be seen in the tissue with a halo of fluorescence around them, suggesting that the proteinase had been secreted into the tissue. Fluorescence was noted only in the vicinity of recognisable $C$. albicans. Blastospores grown in bovine serum-albumin medium were found to fluoresce similarly to those in tissues when treated with rabbit antiproteinase followed by fluorescein-conjugated anti-rabbit immunoglobulin; however, blastospores grown in peptone broth showed only a very weak fluorescence.

\section{Precipitin reactions with sera from experimentally infected rabbits}

CIE titres were determined for PP and CE antigens with sera from a group of rabbits chronically infected with $C$. albicans and with sera from infected rabbits treated with ketoconazole. The sera from the first group contained antibody to both antigens; in all but one case the titre to PP antigen was the same or higher than the titre to CE antigen (table II). Precipitins were not detected in sera from rabbits treated with ketoconazole until 22 days after infection and then a reaction occurred only with the $\mathrm{CE}$ antigen; precipitins to PP antigen were not detected in this group.

\section{TABLE II}

Titres of precipitin to C. albicans cytoplasmic extract and purified proteinase for sera from experimentally infected rabbits

\begin{tabular}{|c|c|c|c|c|c|c|c|c|c|c|c|}
\hline \multirow[t]{2}{*}{$\begin{array}{c}\text { Rabbit } \\
\text { no. }\end{array}$} & \multirow[t]{2}{*}{ Treatment } & \multicolumn{5}{|c|}{$\begin{array}{l}\text { Anti-CE titre } \\
\text { on indicated day } \\
\text { after injection }\end{array}$} & \multicolumn{5}{|c|}{$\begin{array}{l}\text { Anti-PP titre } \\
\text { on indicated day } \\
\text { after injection }\end{array}$} \\
\hline & & 10 & 14 & 22 & 30 & 42 & 10 & 14 & 22 & 30 & 42 \\
\hline 1 & Injection of C. albicans, & 1 & 1 & $\cdots$ & $\cdots$ & 4 & $\begin{array}{l}2 \\
4\end{array}$ & $\begin{array}{l}1 \\
4\end{array}$ & $\cdots$ & $\cdots$ & 8 \\
\hline 3 & $\begin{array}{l}\text { no antifungal } \\
\text { treatment }\end{array}$ & 0 & 2 & $\begin{array}{l}\cdots \\
\cdots\end{array}$ & $\cdots$ & 1 & $\begin{array}{l}4 \\
0\end{array}$ & $\begin{array}{l}4 \\
1\end{array}$ & $\begin{array}{l}\cdots \\
\cdots\end{array}$ & $\begin{array}{l}\cdots \\
\cdots\end{array}$ & 1 \\
\hline $\begin{array}{l}4 \\
5 \\
6\end{array}$ & $\begin{array}{l}\text { Injection of } C \text {. albicans, } \\
4 \times 10^{6} \text { cells } / \mathrm{kg} ; \text { treated } \\
7 \text { days with ketoconazole }\end{array}$ & $\begin{array}{l}0 \\
0 \\
0\end{array}$ & $\begin{array}{l}0 \\
2 \\
0\end{array}$ & $\begin{array}{l}4 \\
8 \\
2\end{array}$ & $\begin{array}{l}2 \\
2 \\
4\end{array}$ & $\begin{array}{l}\cdots \\
\cdots \\
\cdots\end{array}$ & $\begin{array}{l}0 \\
0 \\
0\end{array}$ & $\begin{array}{l}0 \\
0 \\
0\end{array}$ & $\begin{array}{l}0 \\
0 \\
0\end{array}$ & $\begin{array}{l}0 \\
0 \\
0\end{array}$ & $\ldots$ \\
\hline
\end{tabular}

$\mathrm{CE}=$ cytoplasmic extract; $\mathrm{PP}=$ purified proteinase. 
Precipitin reactions by sera from patients with and without systemic candidosis

The results of CIE tests with sera from four groups of patients are shown in table III. None of those from group-1 subjects had antibodies to PP, although five reacted against CE. From the group-2 patients without systemic candidosis and whose sera were negative for precipitins to $\mathrm{CE}$, three serum samples gave a very faint reaction with $\mathrm{PP}$ antigen and 35 were negative.

In group 3 ('false positive' reactors to $\mathrm{CE}$ ), the serum titres against $\mathrm{CE}$

TABLE III

Frequencies of precipitin titres to cytoplasmic extract of $C$. albicans and to purified proteinase in sera from patients with and without candidosis

\begin{tabular}{|c|c|c|c|c|c|c|c|c|}
\hline \multirow{3}{*}{ Titre } & \multicolumn{8}{|c|}{$\begin{array}{l}\text { Number of sera with titre against } \\
\text { indicated antigen, from subjects in }\end{array}$} \\
\hline & \multicolumn{2}{|c|}{ group 1} & \multicolumn{2}{|c|}{ group 2} & \multicolumn{2}{|c|}{ group 3} & \multicolumn{2}{|c|}{ group 4} \\
\hline & $\mathrm{CE}$ & PP & $\mathrm{CE}$ & PP & $\mathrm{CE}$ & PP & CE & PP \\
\hline $\begin{array}{r}0 \\
1 \\
2 \\
4 \\
8 \\
16 \\
32 \\
64\end{array}$ & $\begin{array}{r}52 \\
3 \\
2 \\
0 \\
0 \\
0 \\
0 \\
0\end{array}$ & $\begin{array}{r}57 \\
0 \\
0 \\
0 \\
0 \\
0 \\
0 \\
0\end{array}$ & $\begin{array}{r}38 \\
0 \\
0 \\
0 \\
0 \\
0 \\
0 \\
0\end{array}$ & $\begin{array}{r}35 \\
3 \\
0 \\
0 \\
0 \\
0 \\
0 \\
0\end{array}$ & $\begin{array}{r}0 \\
13 \\
5 \\
4 \\
2 \\
2 \\
0 \\
0\end{array}$ & $\begin{array}{l}6 \\
5 \\
3 \\
7 \\
3 \\
1 \\
1 \\
0\end{array}$ & $\begin{array}{l}1 \\
1 \\
4 \\
4 \\
2 \\
2 \\
2 \\
2\end{array}$ & $\begin{array}{l}0 \\
1 \\
2 \\
2 \\
5 \\
4 \\
2 \\
2\end{array}$ \\
\hline
\end{tabular}

Groap $1=57$ healthy staff and students; group $2=38$ hospital patients without known candidosis; group $3=17$ postoperative patients and 9 with clinical history unknown; group $4=18$ patients with diagnosis of candidosis.

$\mathrm{CE}=$ cytoplasmic extract; $\mathrm{PP}=$ purified proteinase

ranged from 1 to 16 while the titres to $P P$ ranged from 0 to 32 . In two cases the PP titre was 8 or greater and in six the PP titre was higher than the CE titre.

Of the sera from group- 4 patients, diagnosed as having systemic candidosis, eight ( $44 \%$ ) had titres of 8 or greater against $C E$ and one sample gave no reaction. The anti-PP titre was 8 or greater for 13 sera $(72 \%)$; it was lower than the anti-CE titre in only two cases, and there were no negative reactions.

Serial samples of serum were obtained from four patients; the changes in their antibody titres to PP and CE antigens is shown in fig. 6. With the sole exception of serum 3 from patient no. 3, a sample taken during administration of intravenous amphotericin B, proteinase titres were equal to or greater than the CE titres.

\section{Discussion}

The factors responsible for virulence of $C$. albicans are largely unknown. The fungus has been shown to contain toxic macromolecules, such as cell-wall glycoproteins, which are capable of causing fever or even death in experimental animals (Cutler, Friedman and Milner, 1972; Iwata, 1977). The present study provides circumstantial evidence that an extracellular proteinase enzyme, 

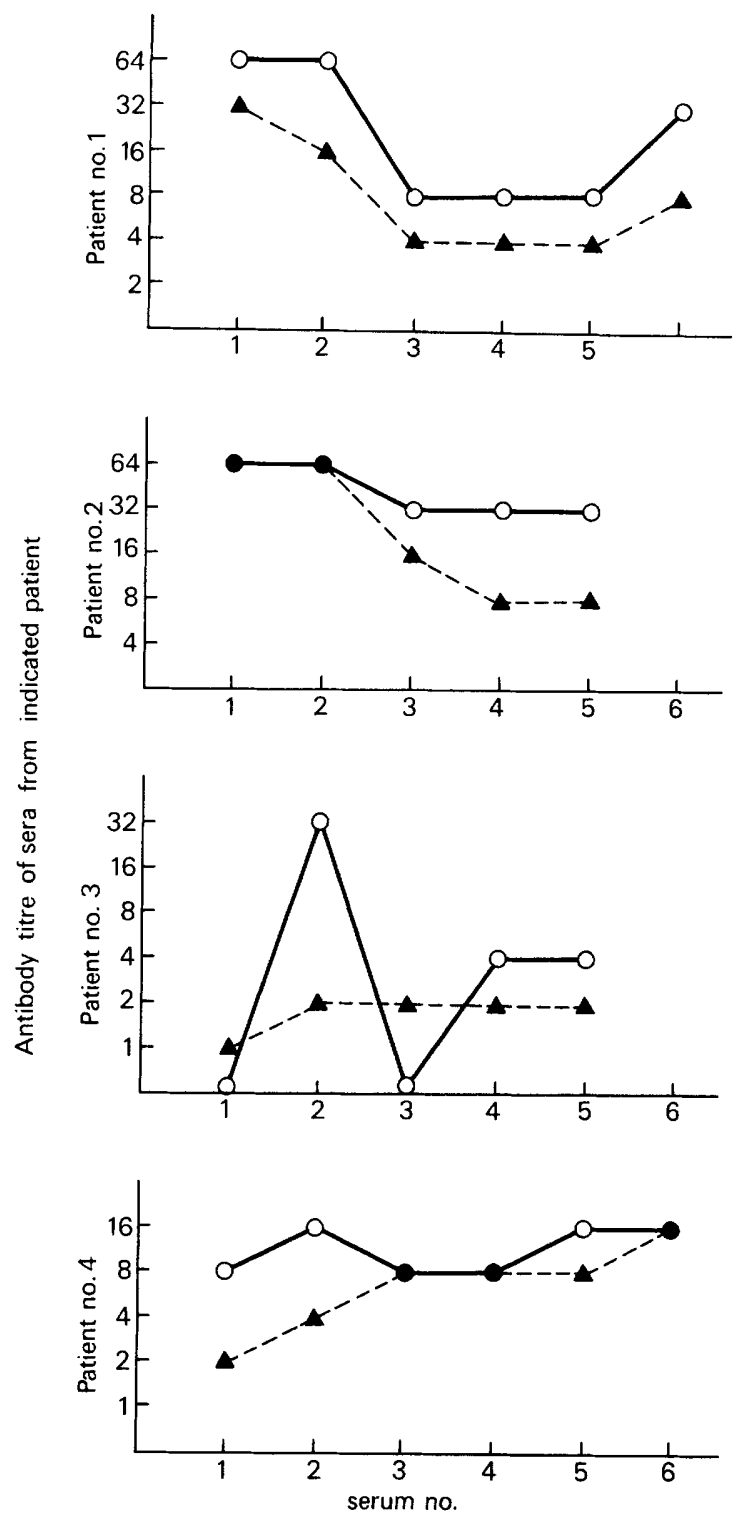

FIG. 6.-Counter-immunoelectrophoresis titres to PP and CE antigens of C. albicans in serial specimens of serum from four patients with systemic candidosis. $0-0=$ Anti-PP titre; $\Delta-\cdots=$ anti-CE titre. Patient no. 1: candidosis secondary to invasive pulmonary infection by Aspergillus fumigatus. Patient no. 2: $C$. albicans septicaemia. Patient no. 3: ulcerative colitis and $C$. albicans septicaemia. Patient no. 4: candida endocarditis.

induced and secreted by $C$. albicans in the presence of protein as sole nitrogen source, may participate in tissue invasion by C. albicans. Previous investigators have provided indirect evidence that proteolysis by Candida isolates is related to their virulence (Staib, 1969; Budtz-Jorgensen, 1974); our demonstration of a zone of candida-infected tissue that showed indirect fluorescence 
with anti-proteinase serum is the first direct evidence for secretion of proteinase in vivo.

The fact that $C$. albicans blastospores in tissues and from broth culture also fluoresced in this test does not negate the evidence for proteinase production in the tissues. Because the enzyme is secreted by the fungus, some activity would be expected to appear in the fungal cells themselves, and this supposition is supported by demonstration of proteinase activity in albumin-grown yeasts. C. albicans blastospores grown in peptone medium showed very little fluorescence with anti-PP; such fluorescence as was seen could be attributed to reaction of anti-PP with cell-wall mannan, because the purified enzyme was found to contain mannan.

The purification scheme described in this study for $C$. albicans proteinase was rapid and effective, and could be easily scaled up for routine production of the enzyme. The method did not appear to remove some Lowry-positive impurities of low molecular weight, which we believe led to a falsely high protein content and therefore an excessively low specific activity for the proteinase. The purified enzyme, a carboxyl proteinase as judged by its susceptibility to inhibition with pepstatin (Barrett, 1977), appeared to be free from other macromolecules in biochemical and serological tests. Although one of the proteins in cytoplasmic extract gave a line coincident with that of purified proteinase in slab PAGE gels, there was no demonstrable acid proteinase activity in the cytoplasmic extract, and no cross reactions between PP and CE antisera or between CE and PP antisera. It is therefore concluded that C. albicans acid proteinase is an antigenically unique molecule.

Staib et al. (1977a and $b$ ) appear to have experienced false-positive antibody reactions against their culture filtrates containing proteinase in sera from a variety of patients without candidosis. The evidence in the present study indicates that purified proteinase has a greater specificity for detection of candidosis than cytoplasmic extracts of the fungus. In rabbits given a highly infective, normally fatal, intravenous inoculum of $C$. albicans, then treated with ketoconazole, there was no indication that candidosis became established (Odds et al., 1980). Antibodies to CE were detected in the sera of these rabbits 22 and 30 days after infection, but antibodies to PP could not be demonstrated at any time. However, in rabbits in which a chronic C. albicans infection was established, precipitins to PP and to CE were detectable 10 days after inoculation. The anti-PP titres were usually greater than the anti-CE titres. These findings suggest that precipitins to PP appear in rabbit sera only when there is tissue invasion by $C$. albicans, whereas candidaemia without tissue invasion leads to anti-CE titres indistinguishable from those in cases of true systemic candidosis.

Such clearcut qualitative specificity for $C$. albicans proteinase was not seen in retrospective tests for $\mathrm{CE}$ and $\mathrm{PP}$ precipitins in human sera. Although no sera from healthy adults reacted with PP, faint precipitin lines with PP were noted in three of 38 CE-negative sera from hospital patients, and anti-PP titres as high as 16 were detected in CE-positive sera from patients without corroborative evidence of systemic candidosis. However, on a quantitative basis the PP 
antigen was substantially more specific than $\mathrm{CE}$ antigen for detection of antibodies in proven cases of systemic candidosis. Among 18 sera from such patients the anti-PP titre was less than the anti-CE titre in only two instances; only in these two sera and in three others was the titre less than 8 . The dual criteria of anti-PP titres greater than 4 and equal to or greater than anti-CE titres were therefore satisfied for $72 \%$ of sera from proven cases. The same criteria were satisfied for only $15 \%$ of sera with 'false positive' C. albicans antibodies. For several of the patients in this group clinical information was not available, so that the possibility of established candidosis in some of the individuals with high anti-PP titres cannot be ruled out.

In the four patients from whom a series of serum specimens was obtained, anti-PP titres were higher than anti-CE titres in all but one instance. The variations with time of anti-PP titres usually paralleled those of anti-CE titres. A fall in candida precipitin titres is considered to indicate resolution of infection (Taschdjian et al., 1973; Odds, 1979). The data therefore suggest that routine sequential tests for antibodies to purified $C$. albicans proteinase would facilitate specificity of diagnosis for systemic candidosis and would indicate total clearance by the disappearance of precipitins to PP.

We consider that our work so far has established purified $C$. albicans proteinase as a diagnostic antigen with potential applicability in routine tests for candidosis. Its full and prospective evaluation in tests with sera from patients for whom complete clinical information is available is now being undertaken.

\section{SUMMARY}

The extracellular acid proteinase of Candida albicans was purified from culture filtrates by a single-column chromatographic step. The purity of the enzyme and its unique antigenic properties were confirmed by polyacrylamidegel electrophoresis and by reaction with homologous and heterologous antisera. The purified enzyme (PP), which was a carboxyl proteinase, contained mannan as an integral part of the molecule. $C$. albicans proteinase was detected in experimental candida kidney lesions by indirect immunofluorescence. Precipitating antibodies to PP and to cytoplasmic extract (CE) were detected in sera from rabbits with chronic, experimental, systemic candidosis; however precipitins to PP were not found in sera from infected rabbits in which tissue invasion was prevented by antifungal treatment. In retrospective tests with sera from healthy subjects and from patients with and without proven systemic candidosis a qualitative distinction between true and false-positive precipitins to PP was not found; however, whereas $72 \%$ of sera from proven cases of deep-seated candida infection had anti-PP titres greater than 4 and greater than or equal to anti-CE titres, these same quantitative criteria were met by only $15 \%$ of sera from patients for whom information of a diagnosis of candidosis was not available. The purified proteinase was therefore a more specific antigen than the widely used cytoplasmic extract for detection of antibodies in cases of candidosis. 
We are grateful to the Medical Research Council for support with a research studentship to one of us (FM), to Mrs A. B. Abbott for technical assistance, and to Professor D. W. R Mackenzie and Drs E. G. V. Evans, N. S. Mair and C. J. Mitchell for their cooperation in provision of patients' sera.

\section{REFERENCES}

AXELSEN, N. H., KRøll, J. AND WeEKe, B. 1973. A manual of quantitative immunoelectrophoresis, methods and applications. Scand. J. Immunol., suppl. 1.

Barrett, A. J. 1977. In Proteinases in mammalian cells and tissues, edited by A. J. Barrett. Elsevier: Amsterdam, p. 1.

Budtz-Jørgensen, E. 1974. Proteolytic activity of Candida spp. as related to the pathogenesis of denture stomatitis. Sabouraudia, 12, 266.

CUtLeR, J. E., Friedman, L. AND Milner, K. C. 1972. Biological and chemical characterization of toxic substances from Candida albicans. Infect. Immun., 6, 616 .

Davis, B. J. 1964. Disc electrophoresis. II. Method and application to serum proteins. Ann. N.Y. Acad. Sci., 121, 404.

DOUCHET, C. AND Müller, J. 1972. Valeur et limites de la sérologie du Candida albicans. Lyon Med., 227, 1129.

Evans, E. G. V. AND Forster, R. A. 1976. Antibodies to Candida after operations on the heart. J. med. Microbiol., 9, 303.

Evans, E. G. V., Richardson, M. D., Odd, F. C. and Holland, K. T. 1973. Relevance of antigenicity of Candida albicans growth phases to diagnosis of systemic candidiasis. $\mathrm{Br}$. med. J., 4, 86.

Everall, P. H., Morris, C. A. AND Morris, D. F. 1974. Antibodies to Candida albicans in hospital patients with and without spinal injury and in normal men and women. J. clin. Path., 27, 722.

Glew, R. H., Buckley, H. R., Rosen, H. M., Moellering, R. C. AND Fischer, J. E. 1975. Value of prospective Candida precipitins in fungaemia in patients with hyperalimentation. Surg. Forum, 26, 113.

Grabar, P. AND Williams, C. A. 1953. Méthode permettant l'étude conjugée des propriétés électrophorétiques et immunochimiques d'un mélange de protéines. Application au sérum sanguin. Biochim. biophys. Acta, 10, 193.

Hotta, K. AND Kurokawa, M. 1968. Separation of fucose and acetylhexosamines by twodimensional thin-layer chromotography. Analyt. Biochem., 26, 472.

IWATA, K. 1977. In Recent advances in medical and veterinary mycology, edited by K. Iwata. University Park Press: Baltimore, p. 15.

Longbottom, J. L., Brighton, W. D., EDGe, G. ANd PePYS, J. 1976. Antibodies mediating type 1 skin test reactions to polysaccharide and protein antigens of Candida albicans. Clin. Allergy, 6, 41 .

Lowry, O. H., Rosebrough, N. J., Farr, L. and Randall, R. J. 1951. Protein measurement with the Folin phenol reagent. J. biol. Chem., 193, 265.

Müller, H. L. 1974. Fortschritte und Probleme der Candidaserologie. Praxis, Berne, 63, 1210.

Murray, I. G., Buckley, H. R. AND Turner, G. C. 1969. Serological evidence of candida infection after open-heart surgery. J. med. Microbiol., 2, 463.

Oblack, D., Schwarz, J. AND Holder, I. A. 1976. Comparative evaluation of the Candida agglutinin test, precipitin test and germ tube dispersion test in the diagnosis of candidiasis. J. clin. Microbiol., 3, 175.

OdDs, F. C. 1979. Candida and candidosis. Leicester University Press: Leicester, p. 224.

Odds, F. C., Evans, E. G. V. AND Holland, K. T. 1975. Detection of Candida precipitins. A comparison of double diffusion and counter immunoelectrophoresis. J. immunol. Meth., 7, 211

Odds, F. C. And Hierholzer, J. C. 1973. Purification and properties of a glycoprotein acid phosphatase from Candida albicans. J. Bact., 114, 257. 
Odd, F. C., Milne, L. J. R., Gentles, J. C. and Ball, E. H. 1980. The activity in vitro and in vivo of a new imidazole antifungal, ketoconazole. J. antimicrob. Chemother., 6, 97.

Parsons, E. R. and Nassau, E. 1974. Candida serology in open heart surgery. J. med. Microbiol., 7, 415 .

Pepys, J., FauX, J. A., Longbottom, J. L., McCarthy, D. S. and Hargreave, F. E. 1968. Candida albicans precipitins in respiratory disease in man. J. Allergy, 41, 305.

Remold, H., Fasold, H. AND STAIB, F. 1968. Purification and characterization of a proteolytic enzyme from Candida albicans. Biochim. Biophys. Acta, 167, 399.

SPIRo, R. G. 1966. Analysis of sugars found in glycoproteins. In Methods in enzymology, vol. 8 , edited by E. F. Neufeld and V. Ginsburg. Academic Press: New York, p. 3.

Staib, F. 1969. Proteolysis and pathogenicity of Candida albicans strains. Mycopath. Mycol. appl., 37, 345.

Staib, F., Focking, M., FröHlich, B. ANd BlisSe, A. 1977a. Candida albicans-Serumpräzipitine bei Blutspendern: Auffällige serologische und kulturelle. Candida albicans-Befunde ber alkoholikern. Mykosen, 20, 423.

StAib, F., Mishra, S. K. AND ABEL, T. L. 1977b. Serodiagnostic value of extracellular antigens of an actively proteolysing culture of Candida albicans. Zentbl. Bakt. ParasitKde, I. Abt. Orig., 238, 284.

Stanley, V. C., Hurley, R. AND CARroll, C. J. 1972. Distribution and significance of candida precipitins in sera from pregnant women. J. med. Microbiol., 5, 313.

Stickle, D., Kaufman, L., Blumer, S. O. and Mclaughlin, D. W. 1972. Comparison of a newly developed latex agglutination test and an immunodiffusion test in the diagnosis of systemic candidiasis. Appl. Microbiol., 23, 490.

SYVERSON, R. E. AND BUCKLEY, H. R. 1977. Cell wall antigens in soluble cytoplasmic extracts of Candida albicans as demonstrated by crossed immuno-affinoelectrophoresis with concanavalin A. J. Immunol. Meth., 18, 149.

Syverson, R. E., BuCKLey, H. R. and CAmpbell, C. C. 1975. Cytoplasmic antigens unique to the mycelial or yeast phase of Candida albicans. Infect. Immun., 12, 1184.

Syverson, R. E., BUCKLEY, H. R. AND Gibian, J. R. 1978. Increasing the predictive value positive of the precipitin test for the diagnosis of deep-seated candidiasis. Am. J. clin. Path., 70, 826.

Taschdian, C. L., Seelig, M. S. And Kozinn, P. J. 1973. Serological diagnosis of candidal infections. Crit. Rev. clin. lab. Sci., 4, 19. 